\title{
Insights into the pathobiology of Paracoccidioides brasiliensis from transcriptome analysis-advances and perspectives
}

\author{
Simoneide S. Silva · Hugo C. Paes · Célia M. A. Soares • \\ Larissa Fernandes · Maria Sueli S. Felipe
}

Received: 11 July 2007 / Accepted: 24 September 2007

(C) Springer Science+Business Media B.V. 2007

\begin{abstract}
Paracoccidioiddes brasiliensis is a thermodimorphic fungus endemic to Latin America, where it causes the most prevalent systemic mycosis, paracoccidioidomycosis (PCM). DNA microarray technology has been used to identify patterns of gene expression when a microbe is confronted with conditions of interest, such as in vitro and/or ex vivo interaction with specific cells. $P$. brasiliensis is one organism that has benefited from this approach. Even though its genome has not been sequenced yet, much has been discovered from its transcriptome and DNA array analyses. In this review, we will outline the current knowledge in P. brasiliensis transcriptome, with focus on differential expression analysis in vitro and on the discussion of the genes that are controlled during the host-pathogen interaction ex vivo in order to give insights into the pathobiology of this fungus. In vitro experiments enabled the delineation of whole metabolic pathways; the description of differential metabolism between mycelium and yeast cells and of the mainly signaling
\end{abstract}

\section{S. S. Silva · H. C. Paes - L. Fernandes ·}

M. S. S. Felipe $(\bowtie)$

Laboratório de Biologia Molecular, Departamento de Biologia Celular, Universidade de Brasília, Brasilia, DF 70910-900, Brazil

e-mail: msueli@unb.br

C. M. A. Soares

Departamento de Bioquímica e Biologia Molecular, Universidade Federal de Goiás, Goiania, GO 74001-970, Brazil pathways controlling dimorphism, high temperature growth, thermal and oxidative stress, and virulence/ pathogenicity. Recent ex vivo experiments provided advances on the comprehension of the plasticity of response and indicate that $P$. brasiliensis is not only able to undergo fast and dramatic expression profile changes but can also discern subtle differences, such as whether it is being attacked by a macrophage or submitted to the bloodstream route conditions.

Keywords Differential gene expression . Host-pathogen interaction - Macrophage response . Paracoccidioides brasiliensis · Transcriptome analysis

\section{Introduction}

The fungus Paracoccidioides brasiliensis is a thermally controlled dimorphic pathogen endemic to Latin America. It causes the most prevalent systemic mycosis, paracoccidioidomycosis (PCM) with around 10 million people infected, of which about $2 \%$ will develop the illness [1]. PCM ranges in clinical onset from an acute infection to a chronic, disseminated form that may compromise several organs besides its initial focus (usually the lungs). Infection is thought to be contracted by inhalation of fungal propagulesconidia or mycelial fragments-and is triggered by the dimorphic shift that characterizes this fungus and which consists of its change upon exposure to the 
body temperature to the yeast form. It is a primary pathogen, infecting immunocompetent hosts, and has a strong bias towards males. The disease is fatal if left untreated and late treatment may result in disabling sequelae.

The phylogenetic classification of $P$. brasiliensis is based primarily on sequence analysis. It is placed alongside other pathogenic, free-living fungi such as Aspergillus fumigatus and Penicillium marneffei inside Phylum Ascomycota, Subphylum Pezizomycotina, and Class Eurotiomycetes. The classification puts it with thermodimorphic Histoplasma capsulatum, Blastomyces dermatitidis and Coccidioides immitis inside Order Onygenales, family Onygenaceae. This classification has been proposed in spite of the fact that no teleomorphic stage has been yet identified for some of them (such a stage is known only for $H$. capsulatum and $B$. dermatitidis among the pathogens). Recent progress on phylogeny of $P$. brasiliensis may be reviewed in detail elsewhere [2]. One of the tasks for the post-genomic era of $P$. brasiliensis will be to establish the cladistic relationships of the fungus with other ascomycetes and trace the history of the interaction of the fungus with animal and human hosts. This will perhaps help us to explain how it evolved to cause PCM and the precise determinants of its virulence.

$P$. brasiliensis has been shown to be refractory to classical genetic analysis. Recently, however, careful analyses have established that it has a genome of 26-35 Mb distributed in four or five chromosomes [3-5]. Ploidy is not consensual; some groups have proposed several isolates to be diploid [3,4], whereas other have used different techniques to propose that most isolates be either haploid or aneuploid [5]. It presents some degree of phenotypic variability; some of them retaining the yeast form even at lower temperatures [6]. Several isolates also differ in their ability to sporulate [7] and cause disease [8]. These presumably reflect a corresponding degree of genetic diversity, which has been supported by recent data [8]. Transcriptome data suggest that the fungus possess sex-related genes [9]. Also, Matute et al. [10] presented compelling evidence of intra-specific recombination, although no sexual reproduction has been detected to date.

Work on genetic variability of $P$. brasiliensis has been carried out for more than a decade. The early works with random amplified polymorphic DNA analysis [11] had already proved to be able to separate isolates into discrete groups. More recent work combining sequencing and phylogenetic analyses has led researchers to postulate the existence of at least three cryptic species [10]; the same group of researchers has also developed a microsatellite analysis protocol that enables the correct classification of isolates according to each phylogenetic species [12].

The genome constitutes the informational core of all biological processes and the study of living organisms depends heavily on our ability to access its contents. For many decades, the experimental approach consisted of isolating single genes or regulatory elements and characterizing each one at a time by means of loss-of-function and/or gain-offunction experiments; or by identifying effectors (proteins, cofactors or metabolites) and studying their roles and interactions.

In keeping with the informational flow in the cell, genome has been closely followed by transcriptome and proteome. The focus of research has shifted from looking into single genes to understanding global processes and refined controls, including the identification of non-coding RNAs and large-scale phenotypic screening of random mutants [13, 14]. Non-coding sequences have attracted much interest in recent years with the discovery and elucidation of RNA interference (RNAi) mechanisms [15]. RNAi has already been used as an experimental tool to characterize genes by means of loss-of-function experiments in organisms that are refractory to common gene disruption mechanisms [16]. None of these phenomena have been explored in $P$. brasiliensis and thus a large avenue of investigation remains to be opened.

The study of pathogens and their interaction with hosts are of special interest. Computer-aided data mining has enabled unambiguous identification of open reading frames, and transcriptional profiling has yielded relevant information concerning differential gene expression [9, 17]. Microarray technology, in conjunction with statistical and experimental validation, has been used to identify patterns of gene expression-selected according to previous genome or transcriptome information-when the microbe is confronted with conditions of interest, such as ex vivo interaction with specific cells or exposure to therapeutic agents, signalling molecules or stressors [18, 19]. The fungus $P$. brasiliensis is one organism that has benefited from these approaches. Even though its 
genome has not been sequenced yet, much has been discovered from the transcriptome and DNA array analyses of this fungus. In this review, we will outline the current knowledge from $P$. brasiliensis transcriptome, with a focus on differential expression analysis in vitro and how it has helped to advance research in recent years. We have also focused on the discussion of the genes that are controlled during the host-pathogen interaction ex vivo in order to give insights into the pathobiology of this fungus.

\section{The transcriptome projects and array studies of $P$. brasiliensis}

The main global gene analysis in P. brasiliensis were performed using the Expressed Sequence Tag (EST) approach, which worked efficiently and seemed to be a useful method to provide the most valuable genetic information of this fungal pathogen. Felipe et al. [9, 20] and Goldman et al. [21] reported the analysis of 6,022 (from $\mathrm{Pb01}$ isolate) and 4,692 (from $\mathrm{Pb} 18$ isolate) assembled groups, respectively. Those first results allowed the delineation of whole metabolic pathways, the differential metabolism between mycelium and yeast cells and the mainly signaling pathways controlling dimorphism, high temperature growth, thermal and oxidative stress, and virulence/ pathogenicity of the fungus. Also, the transcriptome projects highlighted the importance of differential expression genes in both phases-mycelium and yeast, the potentially related virulence factors and possible drug targets.

Among the metabolic features generated by the transcriptome, one of the most interesting found, is the differential metabolism between mycelium and yeast cells of $P$. brasiliensis. The mycelium cells appear to have an aerobic metabolism which is suggested by the up-regulation of isocitrate dehydrogenase and succinyl-CoA synthetase enzymes, involved in citrate cycle and also glucokinase, adenylate kinase, uridine kinase, and transaldolase. On the other hand, the yeast cells presented induction of genes coding alcohol dehydrogenase I and pyruvate dehydrogenase which evidenced an anaerobic metabolic characteristic favoring fermentation of the pathogenic phase of this fungus [9]. The differential metabolism between mycelium and yeast was reinforced by Nunes et al. [22] studies on the transcriptional response of
$P$. brasiliensis during the dimorphism, in which they observed an increased expression of alcohol dehydrogenase I and pyruvate decarboxylase genes in the differentiation process from mycelium to yeast, where almost $90 \%$ of the cells are already in the yeast form.

Marques et al. [23] and Andrade et al. [24] using the array methodology evaluated the differentially expressed genes in mycelium and yeast cells, which in many cases are important keys to understand the pathobiology of $P$. brasiliensis. Andrade et al. [24] reported 66 transcriptional modulated genes in mycelium or yeast categorized into two classes, the first group, cell organization includes genes involved in maintenance of cell wall, membrane and cytoskeleton, as the mycelium up-regulated gene hex which encodes a hexagonal peroxisome protein controlling cell integrity, and $b g l$ coding 1,3- $\beta$-glucosidase involved with cell wall modification during the dimorphism. Among the modulated genes from the yeast phase are verprolin (vrp), chitin deacetylase $(c d a)$, and $\alpha-1$, 3 -glucan synthase (ags). The $\alpha$-1,3-glucan synthase also reported in [23] to be positively regulated in the pathogenic form of $P$. brasiliensis can be easily correlated with the biology of this fungus. The $\alpha-1,3-$ glucan is the main component of the yeast cell wall, and it is closed related to the virulence due to its ability to mask the host recognition mechanism of the pathogen, as also reported in H. capsulatum [25] promoting the fungal escape from the host defenses which contribute to the fungal pathogenesis. The second group of genes consists those involved in metabolism and transport of ions. Genes that regulate the ion metabolism and transport as iron-sulphur cluster (isc) and kpt which is related to potassium availability were positively regulated in mycelium cells. Those genes appear to be involved in availability of iron and potassium, respectively important for the saprophytic life of $P$. brasiliensis on its ecological niche, the soil. The pct gene coding a P-type cation pump is reported to be up-regulated in yeast cells.

The observations of Paris et al. [26] that yeast cells of $P$. brasiliensis were unable to grow in the presence of inorganic sulphur, were confirmed by the array experiments in which the genes coding sulphur metabolism enzymes such as atp sulphurylase, aps kinase, paps redutase and choline sulphatase showed to be up-regulated in yeast cells of this pathogen, indicating the auxotrophic status for cysteine of the pathogenic phase of this fungus [23, 24, 27]. 
The in silico analysis of the transcriptome allowed the identification of almost all components of the conserved signaling pathways already characterized in other eukaryotes as Mitogen activated protein kinases (MAP kinases), Protein kinase $\mathrm{A} /$ cyclic adenosine monophosphate (PKA/cAMP), Ras-GTPases, calcineurin-calmodulin, two component system (histidine kinase), and $G$ proteins coupled receptors [9]. In addition, Nunes et al. [22] using microarray reported activation of genes coding for proteins from conserved signaling pathways during the dimorphic transition from mycelium to yeast of $P$. brasiliensis. Among them were G-proteins, Ser/Thr protein kinases, protein kinase A, calmodulin-like protein, and calcineurin regulatory subunit. Recently, Bastos et al. [28] evaluated the genes regulated on the beginning of cellular transition from mycelium to yeast of $P$. brasiliensis. In accordance, induction of MAP kinases, calcineurin regulatory subunit, serine/threonine kinases and also the histidine kinase and two component sensor kinases was observed [22]. The histidine kinase gene (drk) was reported to control the global dimorphism in fungal pathogens [14]. These studies suggest the involvement of those signaling pathways in the cellular differentiation process of $P$. brasiliensis.

Fungal pathogens use the conserved mechanism of signaling to promote cell survival under different conditions. The activation of virulence factors is also dependent of the signaling triggered by those cascades, and the main consequence of this activation is the ability of the pathogen to infect and disseminate on the harsh host environment. By a comparison of the P. brasiliensis ESTs with Candida albicans genes, Felipe et al. [9] identified some genes potentially related to fungal virulence. In a more detailed search scan, Tavares et al. [29] categorized 30 putative virulence genes into the following classes: metabolism, cell wall, detoxification-related, secreted factors, and others. Genes as icll and mlsl coding respectively, isocitrate lyase and malate synthase of the glyoxylate cycle were potentially correlated with virulence due to their activation on poor carbon growth conditions. As those enzymes are not present in humans, they are also possible drug targets candidates. Other genes related to virulence are identified such as: phosphoribosylaminoimidazole carboxylase (ade2), N-myristoyltransferase (nmtl) and fatty acid synthase $\alpha$-subunit (fas 2 ), trehalose-6phosphate synthase (tps1), respectively involved in nucleotide, lipids and glucose metabolism. Among the genes from the second group are those necessary to the cell wall integrity during the vegetative growth and differentiation of $P$. brasiliensis, and includes: $\alpha$-glucan-synthase gene (ags1), chitin synthase 3 (chs3), glucosamine-6-phosphate acetyltransferase (gnal), mannosyl transferase (pmtl) and $\alpha$-1,2-mannosyltransferase (mntl), phrl and $p h r 2$ (1,3- $\beta$-glucanosyltransferases). The third group comprises the pathogen virulence genes that function on the detoxification of oxidative radicals: as $\mathrm{Cu} / \mathrm{Zn}$ superoxide dismutase ( $\operatorname{sod} l)$, thiol peroxidase (tsal) alternative oxidase (aoxl), and catalase (catl). As $P$. brasiliensis is a pathogen that survives intracellularly, the yeast cells have to minimize the toxic substances present in the phagossomes of the macrophage cells, and by this reason, the fungus exhibits an antioxidant arsenal of enzymes that are necessary to the survival and consequently virulence of the pathogen. The secreted virulence factors, also reported by Tavares et al. [29] include genes encoding proteinases, phospholipases, and urease.

The in vitro transcriptome studies opened a new window on the understanding of $P$. brasiliensis biology. Recently, the genes modulated in the hostpathogen interaction were evaluated trough the transcriptional response of $P$. brasiliensis when yeast cells were internalized into macrophage cells [30]. In addition, Bailão et al. [31] also analyzed genes with differential expression when yeast cells were in contact with human blood and rescued from infected mice, to identify the genes required to the $P$. brasiliensis adaptation on the host interaction.

\section{Global patterns of gene expression in the host-pathogen interaction}

Understanding host-pathogen interactions may provide insights into host defences and the tactics used by pathogens to overcome them. In recent years, several approaches such as cDNA microarrays, cDNA representational difference analysis (RDA) and serial analysis of gene expression (SAGE) have been developed to identify general profiles of gene expression [32, 33]. Specifically, the cDNA microarray technology has been applied to the analysis of bacterial and fungal interactions with phagocytes, 
thus identifying key effectors of pathogen virulence and host defence [32, 34-36].

\section{Transcriptional profile of $\boldsymbol{P}$. brasiliensis upon infection}

The first defence line encountered by $P$. brasiliensis upon infection is pulmonary resident macrophages. Despite being phagocytized, P. brasiliensis conidia germinate into the parasitic yeast form, which is equipped to resist the harsh intraphagosomal environment, thus surviving and replicating in non-activated murine and human macrophages. It has been proposed, for PCM and for other systemic mycoses such as histoplasmosis and coccidioidomycosis, that fungal intracellular parasitism is a landmark event for establishment and progression of disease in susceptible hosts, since it enables fungal latency and/or dissemination from the lungs to other organs and tissues [37]. The understanding of this process should reveal key aspects of how these pathogens manage to survive and replicate intracellularly and eventually lead to the development of new antimicrobial drugs.

The macrophage phagosome is believed to be a poor source of glucose and amino acids [18, 38]. Nutritional deprivation inside the macrophage induces a similar adaptative response by intracellular bacterial and fungal pathogens [18, 38, 39]. Microarray analysis showed that following phagocytosis, C. albicans and Listeria monocytogenes present a strong reduction in the expression of genes involved in glycolysis and amino acid metabolism [38, 39]. In order to focus the research on the interaction of $P$. brasiliensis with the human host, 1,152 cDNA clones of interest were selected from the transcriptional database, based on previous findings of $P$. brasiliensis transcriptome [9], including putative virulence factors, general metabolism enzymes, heat shock proteins, cell wall synthetic enzymes and also some of unknown function. In addition, the protocol of RNA extraction from $P$. brasiliensis yeast cells internalized by murine macrophages, without any additional fungal in vitro growth was standardized [30]. They observed that early phagocytized $P$. brasiliensis also sense and respond to the phagosomal environment. Genes implicated in glucose and amino acid depletion ( $p f k A$, phosphofructokinase; gapdh, glyceraldehyde-3-phosphate dehydrogenase; $p g k$, phosphoglycerate kinase; gрma, phosphoglycerate mutase; eno, enolase; met $G$, cystathionine $\beta$-lyase), cell wall metabolism ( $f k s$, $\alpha$-glucan synthase), and oxidative stress ( $\operatorname{sod} 3, \mathrm{Cu}, \mathrm{Zn}$ superoxide dismutase and $h s p 60,60 \mathrm{kDa}$ heat shock protein) were differentially expressed by $P$. brasiliensis upon macrophage infection. The data showed a considerable degree of transcriptional plasticity by $P$. brasiliensis in response to the hostile environment of macrophages, which is expected to underlie its adaptability and consequent survival inside that cell [30].

From the primary site in the lungs, PCM may evolve with fungal dissemination via the bloodstream and/or lymphatic system to many organs [40]. Recently, using cDNA-RDA technology, Bailão et al. [31] reported the differential expression profile of $P$. brasiliensis in conditions that mimic the haematological route of fungal propagation. Under such conditions, several genes, including a transport facilitator (ctr3), stress response proteins $(30,70$ and $90 \mathrm{kDa}$ heat shock proteins-hsp30, hsp70 and hsp90), and cell wall remodelling ( $s h o l$, transmembrane osmosensor; pas-like-protein with PYP-like sensor domain, PAS domain; septin-1), were induced upon blood contact.

Nutrient deprivation inside the phagosome induces a similar adaptive response from intracellular bacterial and fungal pathogens and early phagocytized $P$. brasiliensis also sense and respond to the glucosedepleted environment, repressing genes related to glycolysis and amino acid synthesis. In contrast, when $P$. brasiliensis are exposed to blood, genes related to glucose and amino acid metabolism are induced, probably because the milieu is quite rich. Similar results were described upon incubation of C. albicans in human blood [41].

After internalization, macrophages challenge the pathogens releasing a group of toxic antimicrobial molecules, including reactive oxygen and nitrogen intermediates (ROI and RNI, respectively). In response to the oxidative stress generated by the macrophage, the $P$. brasiliensis counter attacks inducing antioxidant gene such as $\operatorname{sod} 3$ [30]. In silico analysis showed that the deduced amino acid sequence of the $P$. brasiliensis sod 3 homologue codes a putative membrane GPI-anchored $\mathrm{Cu}, \mathrm{Zn}$ SOD [42], which would make it more directly accessible to host-derived superoxide anions and thus be more efficient at ROI detoxification. This idea is reinforced by $C$. albicans 
GPI-anchored $\mathrm{Cu}, \mathrm{Zn}$ SOD gene, which is induced in vitro by oxidative species generators and upon internalization by neutrophils [41, 43]. Also, genes encoding molecules involved with thermal stressresponse as $h s p 60$ were induced when $P$. brasiliensis was ingested by macrophages [30] as well as in exposure to blood as $h s p 30, h s p 70$, and $h s p 90$ [31]. These proteins may contribute to the protection of $P$. brasiliensis yeast cells from damage following stress, which occur during infection.

Of particular interest for PCM pathogenesis are the genes involved in cell wall remodelling. The gene for $\beta$-glucan synthase ( $f k s)$ is down-regulated in response to the macrophage environment. It has been shown for $P$. brasiliensis and other fungi that the degree of virulence from different isolates in an experimental model of murine infection is related to the relative $\alpha-\beta$-glucan levels present in their cell wallavirulent yeast isolates contain less $\alpha$ - and more $\beta$-glucan $[44,45]$. The mechanism of $\beta$-glucan host protection may be related to its capacity to stimulate inflammatory mediators such as tumor necrosis factor-alpha (TNF- $\alpha)$. Since TNF- $\alpha$ has been associated with resistance to $P$. brasiliensis [46, 47], fks down-regulation may be an important adaptive mechanism of $P$. brasiliensis to reduce the inflammatory response elicited by the host [30]. In addition, transcripts related to remodelling cell wall and osmotic stress ( $g \ln 1$, glutamine synthetase; septin-1, shol, pas-like) were also induced in P. brasiliensis upon blood contact [31]. The induction of $g \ln 1$ and septin-1 has been speculated to be important in the mediation of chitin deposition. Chitin synthesis has been shown to be essential in the compensatory response to cell wall stress in fungi, preventing cell death [48]. The shol and pas-like genes belong to different classes of osmotic stress sensors. In C. albicans, shol is related to fungal morphogenesis by interconnecting two pathways involved in cell wall biogenesis and oxidative stress [49]. Up-regulation of shol and pas-like implies their involvement in osmolarity sensing during fungal dissemination through the blood. Figure 1 shows the proposed model for adaptative changes of $P$. brasiliensis to the host environment, considering the environment of macrophage cells and exposure to blood.

The transcriptional programme of macrophageingested cells displays little resemblance to that obtained from $P$. brasiliensis cells exposed to blood.
These pioneering works provided advances on the comprehension of the plasticity of response and indicate that $P$. brasiliensis is not only able to undergo fast and dramatic expression profile changes but can also discern even subtle differences, such as whether it is being attacked by a macrophage or submitted to the bloodstream route conditions.

\section{Transcriptional response of macrophage cells upon infection with $P$. brasiliensis}

The host cell response to pathogens is among the best studied examples of cellular reactions to external stimuli. Pathogen-induced phenotypic changes in host cells are often accompanied by marked changes in gene expression. DNA microarray technology has greatly expanded our ability to monitor changes in the abundance of transcripts in a host upon infection with a microorganism. Macrophages, neutrophils and peripheral blood mononuclear cells (PBMCs) respond to a broad range of microbial stimuli with common transcriptional activation programmes [32, $36,50]$. In this regard, microarray analyses have shown an increase of genes related to innate immunity in macrophages infected with Mycobacterium tuberculosis, C. albicans and A. fumigatus [35, 36, 51]. Recently, for the first time, Silva et al. (in press) [52] used cDNA microarray analysis to identify differential genes of macrophages infected with $P$. brasiliensis that are related to several immune processes such as inflammation, cell membrane regulation, transcriptional regulation, signal transduction, and apoptosis. This last work and the results obtained by Tavares et al. [30] studies provided the first data of differential gene expression from host $-P$. brasiliensis interaction, at $6 \mathrm{~h}$ of infection, the same time and experimental conditions. In this sense, we have reported by cDNA microarray analysis that, in response to the harsh macrophage microenvironment, $P$. brasiliensis expressed genes primarily associated with glucose and amino acid limitation, cell wall construction, and oxidative stress [30]. In counterpart, macrophages at the same time point up-regulate genes related to inflammation (chemokines and cytokines) and phagocytosis, probably as an effort to avoid host fungal dissemination into different organs and tissues [52]. 


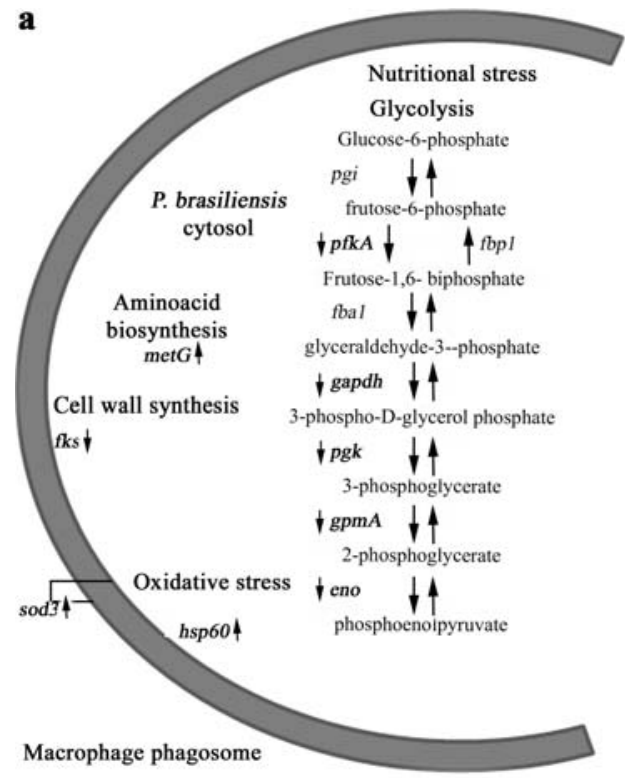

Fig. 1 Model for adaptative changes of $P$. brasiliensis to the host environment. The small arrows $\uparrow$ and $\downarrow$ indicated induced and repressed genes, respectively. (a) $P$. brasiliensis survival in macrophage phagosome: oxidative and thermal stress-sod3, and hsp60; nutritional stress (aminoacid byosynthesis)$m e t G$; glycolysis—pfkA, gapdh, pgk, gpma and eno; cell wall

\section{Concluding remarks}

For many decades, genetic information of $P$. brasiliensis was not easily and widely accessed at the molecular level in order to gain information about the biology, virulence, pathogenicity, interaction with the host and onset of disease. In recent years, the new approach of global gene expression analysis gave us the opportunity to understand the general and differential metabolism in both phases of the dimorphic fungus. In addition, it has made possible the identification of potential candidate molecules that contribute to virulence, pathogenicity and others that may be used for drug targeting. Furthermore, it has opened the possibility to access the whole transcriptional response during host-pathogen interaction. Finally, the identification of genes that are differentially expressed under in vitro dimorphic transition experiments, ex vivo macrophage infection or exposure of $P$. brasiliensis to blood has advanced current knowledge to a better understanding of PCM.

As a main consequence of post-transcriptome analysis, the scientific community around P. brasiliensis is allocating efforts in order to develop an b

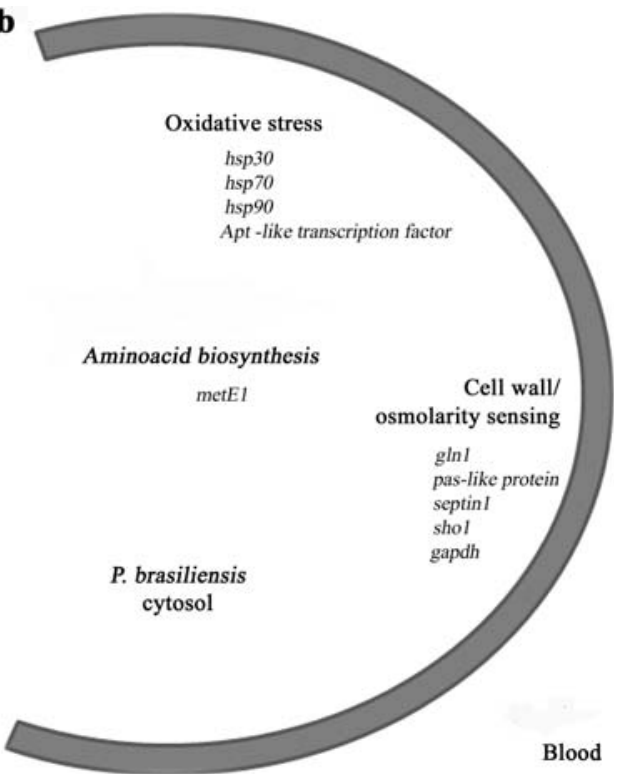

synthesis— $f k s$ [30]. (b) Induction of $P$. brasiliensis genes during blood exposure: thermal stress-hsp30, hsp70 and hsp90, Apl-like transcription factor; nutritional response-metE1 (s-adenosylmethionine synthetase); cell wall/osmolarity sensinggln1, pas-like protein, septin, shol and gapdh [31]

efficient genetic toolbox to prove and validate the gene function of many of those candidate genes highlighted by the transcriptome data. For example, the generation of random, T-DNA insertional mutants of fungi by means of co-cultivation with Agrobacterium tumefaciens has proved to be a powerful technique that has solved at least one major question in the biology of dimorphic fungi [14]. The molecular toolbox to implement this approach in P. brasiliensis is still to be developed. Furthermore, these data contribute to a global picture of this systemic illness that may help us to devise comprehensive therapeutic approaches in the near future.

Acknowledgments This work was supported by FAP-DF/ $\mathrm{CNPq}$ and MCT/CNPq and FUB. SSS, LF and HCP were supported by CNPq fellowship.

\section{References}

1. Restrepo A, Tobón A. Paracoccidioides brasiliensis. In: Mandell GL, Bennett JE, Dollin R, editors. Principles and practice of infectious diseases. Philadelphia; 2005. pp. 3062-8. 
2. Bagagli E, Bosco SMG, Theodoro RC, Franco M. Phylogenetic and evolutionary aspects of Paracoccidioides brasiliensis reveal a long coexistence with animal hosts that explains several biological features of the pathogen. Infect Genet Evol 2006;6:344-51.

3. Cano MI, Cisalpino PS, Galindo I, Ramirez JL, Mortara RA, da Silveira JF. Electrophoretic karyotypes and genome sizing of the pathogenic fungus Paracoccidioides brasiliensis. J Clin Microbiol 1998;36:742-7.

4. Feitosa LS, Cisalpino PS, dos Santos MRM, Mortara RA, Barros TF, Morais FV, Puccia R, da Silveira JF, Camargo ZP. Chromosomal polymorphism, syntenic relationships, and ploidy in the pathogenic fungus Paracoccidioides brasiliensis. Fungal Genet Biol 2003;39:60-9.

5. Almeida AJ, Matute DR, Carmona JA, Martins M, Torres I, McEwen JG, Restrepo A, Leão C, Ludovico P, Rodrigues F. Genome size and ploidy of Paracoccidioides brasiliensis reveals a haploid DNA content: flow cytometry and GP43 sequence analysis. Fungal Genet Biol 2007; 44:25-31.

6. Villar LA, Salazar ME, Restrepo A. Morphological study of a variant of Paracoccidoides brasiliensis that exists in the yeast form at room temperature. J Med Vet Mycol 1988;26:269-76.

7. McEwen JG, Restrepo BI, Salazar ME, Restrepo A. Nuclear staining of Paracoccidioides conidia. J Med Vet Mycol 1987;25:343-5.

8. Kurokawa CS, Lopes CR, Sugizaki MF, Kuramae EE, Franco MF, Peraçoli MTS. Virulence profile of ten Paracoccidioides brasiliensis isolates. Association with morphologic and genetic patterns. Rev Inst Med Trop Sao Paulo 2005;47:257-62.

9. Felipe MS, Andrade RV, Arraes FB, Nicola AM, Maranhao AQ, Torres FA, Silva-Pereira I, Pocas-Fonseca MJ, Campos EG, Moraes LM, Andrade PA, Tavares AH, Silva SS, Kyaw CM, Souza DP, Pereira M, Jesuino RS, Andrade EV, Parente JA, Oliveira GS, Barbosa MS, Martins NF, Fachin AL, Cardoso RS, Passos GA, Almeida NF, Walter ME, Soares CM, Carvalho MJ, Brigido MM. PbGenome network. Transcriptional profiles of the human pathogenic fungus Paracoccidioides brasiliensis in mycelium and yeast cells. J Biol Chem 2005;280:24706-14.

10. Matute DR, McEwen JG, Puccia R, Montes BA, San-Blas G, Bagagli E, Rauscher JT, Restrepo A, Morais F, NinoVeja G, Taylor JW. Cryptic speciation and recombination in the fungus Paracoccidioides brasileinsis as revealed by gene genealogies. Infect Genet Evol 2006;6:344-51.

11. Soares CM, Madlun EE, da Silva SP, Pereira M, Felipe MS. Characterization of Paracoccidioides brasiliensis isolates by random amplified polymorphic DNA analysis. J Clin Microbiol 1995;33:505-7.

12. Matute DR, Sepulveda VE, Quesada LM, Goldman GH, Taylor JW, Restrepo A, McEwen JG. Microsatellite analysis of three phylogenetic species of Paracoccidioides brasiliensis. J Clin Microbiol 2006;44:2153-7.

13. Numata K, Kanai A, Saito R, Kondo S, Adachi J, Wilming LG, Hume DA, RIKEN GER Group GSL Members, Hayashizaki Y, Tomita M. Identification of putative noncoding RNAs among the RIKEN mouse full-length cDNA collection. Genome Res 2003;13:1301-6.
14. Nemecek JC, Wuthrich M, Klein BS. Global control of dimorphism and virulence in fungi. Science 2006;312: 583-8.

15. Agrawal N, Dasaradhi PVM, Mohmmed A, Malhotra P, Bhatnagar RK, Mukherjee SK. RNA interference, biology, mechanism, and applications. Microbiol Mol Biol Rev 2003;67:657-85.

16. Nakayashiki H. RNA silencing in fungi: mechanisms and applications. FEBS Lett 2005;579:5950-7.

17. Galagan JE, Calvo SE, Cuomo C, Ma L, Wortman JR, Batzoglou S, Lee S, Bastürkmen M, Spevak CC, Clutterbuck J, Kapitonov V, Jurka J, Scazzocchio C, Farman M, Butler J, Purcell S, Harris S, Braus GH, Draht O, Busch S, D'Enfert C, Bouchier C, Goldman GH, BellPedersen D, Griffiths-Jones S, Doonan JH, Yu J, Vienken K, Pain A, Freitag M, Selker EU, Archer DB, Peñalva MA, Oakley BR, Momany M, Tanaka T, Kumagai T, Asai K, Machida M, Nierman WC, Denning DW, Caddick M, Hynes M, Paoletti M, Fischer R, Miller B, Dyer P, Sach MS, Osmani SA, Birren BW. Sequencing of Aspergillus nidulans and comparative analysis with A. fumigatus and A. oryzae. Nature 2005;438:1105-15.

18. Fan W, Kraus PR, Boily MJ, Heitman J. Cryptococcus neoformans gene expression during murine macrophage infection. Eukaryot Cell 2005;4:1420-33.

19. Rasmussen TB, Skindersoe ME, Bjarnsholt T, Phipps RK, Christensen KB, Jensen PO, Andersen JB, Koch B, Larsen TO, Hentzer M, Eberl L, Hoiby N, Givskov M. Identity and effects of quorum-sensing inhibitors produced by Penicillium species. Microbiology 2005;151:1325-40.

20. Felipe MS, Andrade RV, Petrofeza SS, Maranhao AQ, Torres FA, Albuquerque P, Arraes FB, Arruda M, Azevedo MO, Baptista AJ, Bataus LA, Borges CL, Campos EG, Cruz MR, Daher BS, Dantas A, Ferreira MA, Ghil GV, Jesuino RS, Kyaw CM, Leitao L,Martins CR, Moraes LM, Neves EO, Nicola AM, Alves ES, Parente JA, Pereira M,Pocas-Fonseca MJ, Resende R, Ribeiro BM, Saldanha RR, Santos SC, Silva-Pereira I, Silva MA, Silveira E, Simoes IC, Soares RB, Souza DP, De-Souza MT, Andrade EV, Xavier MA, Veiga HP, Venancio EJ, Carvalho MJ, Oliveira AG, Inoue MK, Almeida NF, Walter ME, Soares CM, Brigido MM. Transcriptome characterization of the dimorphic and pathogenic fungus Paracoccidioides brasiliensis by EST analysis. Yeast. 2003;20:263-71.

21. Goldman GH, dos Reis Marques E, Duarte Ribeiro DC, de Souza Bernardes LA, Quiapin AC, Vitorelli PM, Savoldi M, Semighini CP, de Oliveira RC, Nunes LR, Travassos LR, Puccia R, Batista WL, Ferreira LE, Moreira JC, Bogossian AP, Tekaia F, Nobrega MP, Nobrega FG, Goldman MH. Expressed sequence tag analysis of the human pathogen Paracoccidioides brasiliensis yeast phase: identification of putative homologues of Candida albicans virulence and pathogenicity genes. Eukaryot Cell 2003;2:34-48.

22. Nunes LR, Costa de Oliveira R, Leite DB, da Silva VS, dos Reis Marques E, da Silva Ferreira ME, Ribeiro DC, de Souza Bernardes LA, Goldman MH, Puccia R, Travassos LR, Batista WL, Nobrega MP, Nobrega FG, Yang DY, de Braganca Pereira CA, Goldman GH. Transcriptome analysis of Paracoccidioides brasiliensis cells undergoing 
mycelium-to-yeast transition Eukaryot Cell. 2005;14: 2115-28.

23. Marques ER, Ferreira ME, Drummond RD, Felix JM, Menossi M, Savoldi M, Travassos LR, Puccia R, Batista WL, Carvalho KC, Goldman MH, Goldman GH. Identification of genes preferentially expressed in the pathogenic yeast phase of Paracoccidioides brasiliensis, using suppression subtraction hybridization and differential macroarray analysis. Mol Genet Genomics 2004;271: 667-77.

24. Andrade RV, Paes HC, Nicola AM, de Carvalho MJ, Fachin AL, Cardoso RS, Silva SS, Fernandes L, Silva SP, Donadi EA, Sakamoto-Hojo ET, Passos GA, Soares CM, Brigido MM, Felipe MS. Cell organisation, sulphur metabolism and ion transport-related genes are differentially expressed in Paracoccidioides brasiliensis mycelium and yeast cells. BMC Genomics 2006;7:208.

25. Rappleye CA, Eissenberg LG, Goldman WE. Histoplasma capsulatum alpha-(1,3)-glucan blocks innate immune recognition by the beta-glucan receptor. Proc Natl Acad Sci USA 2007;104:1366-70.

26. Paris S, Duran-Gonzalez S, Mariat F. Nutritional studies on Paracoccidioides brasiliensis: the role of organic sulfur in dimorphism. Sabouraudia 1985;23:85-92.

27. Ferreira ME, Marques Edos R, Malavazi I, Torres I, Restrepo A, Nunes LR, de Oliveira RC, Goldman MH, Goldman GH. Transcriptome analysis and molecular studies on sulfur metabolism in the human pathogenic fungus Paracoccidioides brasiliensis. Mol Genet Genomics 2006;276:450-63.

28. Bastos KP, Bailao AM, Borges CL, Faria FP, Felipe MS, Silva MG, Martins WS, Fiuza RB, Pereira M, Soares CM. The transcriptome analysis of early morphogenesis in Paracoccidioides brasiliensis mycelium reveals novel and induced genes potentially associated to the dimorphic process. BMC Microbiol 2007;7:29.

29. Tavares AH, Silva SS, Bernardes VV, Maranhao AQ, Kyaw CM, Pocas-Fonseca M, Silva-Pereira I. Virulence insights from the Paracoccidioides brasiliensis transcriptome. Genet Mol Res 2005;4:372-89.

30. Tavares AH, Silva SS, Dantas A, Campos EG, Andrade RV, Maranhão AQ, Brígido MM, Passos-Silva DG, Facchin AL, Teixeira SM, Passos GA, Soares CM, Bocca AL, Carvalho MJ, Silva-Pereira I, Felipe MSS. Early transcriptional response of Paracoccidioides brasiliensis upon internalization by murine macrophages. Microbes Infect 2007;9:583-90.

31. Bailão AM, Schrank A, Borges CL, Dutra V, Walquiria Ines Molinari-Madlum EE, Soares Felipe MS, Soares Mendes-Giannini MJ, Martins WS, Pereira M, Maria de Almeida Soares C. Differential gene expression by Paracoccidioides brasiliensis in host interaction conditions: representational difference analysis identifies candidate genes associated with fungal pathogenesis. Microbes Infect 2006;8:2686-97.

32. Nau GJ, Richmond JFL, Schlesinger A, Jennings EG, Lander ES. Human macrophage activation programs induced by bacterial pathogens. Proc Natl Acad Sci USA 2000;99:1503-08.

33. Dutra V, Nakazato L, Broetto L, Schrank IS, Vainstein $\mathrm{MH}$, Schrank A. Application of representational difference analysis to identify sequence tags expressed by Metarhizium anisopliae during the infection process of the tick Boophilus microplus cuticle. Res Microbiol 2004;155: 245-51.

34. Eskra L, Mathison A, Splitter R. Microarray analysis of mRNA levels from RAW264.7 macrophages infected with Brucella abortus. Infect Immun 2003;71:1125-33.

35. Kim HS, Choi EH, Khan J, Roilides E, Francesconi A, Kasai M, Sein T, Schaufele RL, Sakurai K, Son CG, Greer BT, Chanock S, Lyman CA, Walsh TJ. Expression of genes encoding innate host defense molecules in normal human monocytes in response to Candida albicans. Infect Immun 2005;73:3714-24.

36. Cortez KJ, Lyman CA, Kottilil S, Kim HS, Roilides E, Yang J, Fullmer B, Lempicki R, Walsh TJ. Functional genomics of innate host defense molecules en normal human monocytes in response to Aspergillus fumigatus. Infect Immun 2006;74:2353-65.

37. Brummer E, Hanson LH, Restrepo A, Stevens DA. Intracellular multiplication of Paracoccidioides brasiliensis in macrophages: killing and restriction of multiplication by activated macrophages. Infect Immun 1989;57:228994.

38. Lorenz MC, Bender JA, Fink GR. Transcriptional response of Candida albicans upon internalization by macrophages. Eukaryot Cell 2004;3:1076-87.

39. Chatterjee SS, Hossain H, Otten S, Kuenne C, Kuchmina K, Machata S, Domann E, Chakraborty T, Hain T. Intracellular gene expression profile of Listeria monocytogenes. Infect Immun 2006;74:1323-38.

40. Franco M, Peracoli MT, Soares A, Montenegro R, Mendes RP, Meira DA. Host-parasite relationship in paracoccidioidomycosis. Curr Top Med Mycol 1993;5:115-49.

41. Fradin C, Kretschmar Nichterlein T, Gaillardin C, d'Enfert C, Hube B. Stage-specific gene expression of Candida albicans in human blood. Mol Microbiol 2003;47:152343.

42. Castro NS, Maia ZA, Pereira M, Soares CM. Screening for glycosylphosphatidylinositol-anchored proteins in the Paracoccidioides brasiliensis transcriptome. Genet Mol Res 2005;4:326-345.

43. Martchenko MA, Alarco M, Harcus D, Whiteway M. Superoxide dismutases in Candida albicans: transcriptional regulation and functional characterization of the hyphal-induced SOD5 gene. Mol Biol Cell 2004;15: 456-67.

44. San-Blas G, San-Blas F. Paracoccidioides brasiliensis: cell wall structure and virulence-a review. Mycopathologia 1977;62:77-86.

45. Klimpel KR, Goldman WE. Cell walls from avirulent variants of Histoplasma capsulatum lack alpha-(1,3)-glucan. Infect Immun 1988;56:2997-3000.

46. Calvi SA, Peracoli MT, Mendes RP, Marcondes-Machado J, Fecchio D, Marques SA, Soares AM. Effect of cytokines on the in vitro fungicidal activity of monocytes from paracoccidioidomycosis patients. Microbes Infect 2003;5: 107-13.

47. Souto JT, Figueiredo F, Furlanetto A, Pfeffer K, Rossi MA, Silva JS. Interferongamma and tumor necrosis factor-alpha determine resistance to Paracoccidioides brasiliensis infection in mice. Am J Pathol 2000;156:1811-20. 
48. Ram AF, Arentshorst M, Damueld RA, Vankuyk PA, Klis FM, van den Hondel CAMJJ. The cell wall stress response in Aspergillus niger involves increased expression of the glutamine: fructose-6-phosphate amidotransferase-encoding gene $(\mathrm{gfaA})$ and increased deposition of chitin in the cell wall. Microbiology 2004;15:3315-26.

49. Roman E, Nombela C, Pla J. The sho1 adaptor protein links oxidative stress to morphogenesis and cell wall biosynthesis in the fungal pathogen Candida albicans. Mol Cell Biol Rev 2005;25:10611-27.

50. Boldrick JC, Alizadeh AA, Diehn M, Dudoit S, Liu CL, Belcher CE, Botstein D, Staudt LM, Brown PO, Relman DA. Stereotyped and specific gene expression programs in human innate immune responses to bacteria. Proc Natl Acad Sci USA 2002;99:972-7.

51. Wang JP, Rought SE, Jacques C, Guiney DG. Gene expression profiling detects patterns of human macrophage responses following Mycobacterium tuberculosis infection. FEMS Immun Med Microb 2003;39:163-72.

52. Silva SS, Tavares AH, Passos-Silva DG, Facchin AL, Teixeira SM, Soares CM, Bocca AL, Carvalho MJ, SilvaPereira I, Passos GA, Felipe MS. Transcriptional response of murine macrophages upon infection with opsonized Paracoccidioides brasiliensis. Microbes Infect 2007; MICINF-D-07-00160R1. 